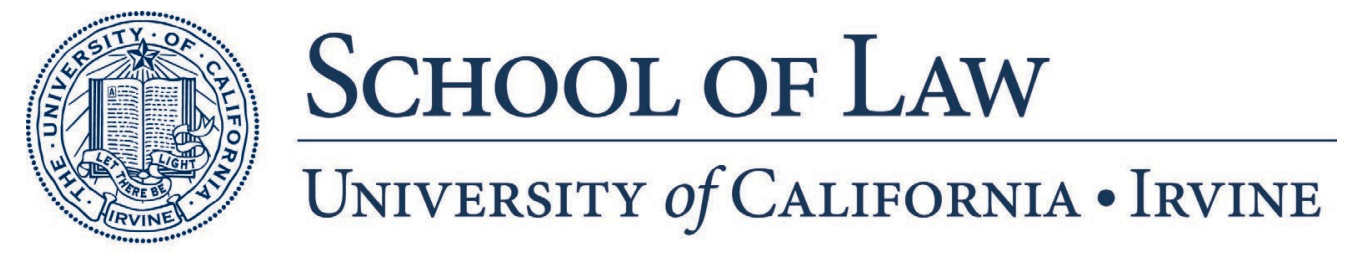

Legal Studies Research Paper Series No. 2021-13

The Concept of a Global Legal System

(Chapter IN: The Many Lives of Transnational Law: Critical Engagements with Jessup's Bold Proposal, Peer Zumbansen, ed., Cambridge University Press 2020)

Christopher Whytock

cwhytock@law.uci.edu

University of California, Irvine School of Law 


\title{
The ConcePt of a Global Legal System
}

\author{
In The Many Lives of Transnational Law: Critical Engagements with Jessup's Bold \\ Proposal (Peer Zumbansen, ed., Cambridge University Press 2020) \\ Christopher A. Whytock \\ University of California, Irvine \\ March 4, 2019 Preprint Version \\ Please Cite to Final Published Version
}

\section{INTRODUCTION}

The international law field of teaching and scholarship focuses - and has long focusedon the so-called "international legal system." 1 The system's parts include international law, international courts, and international organizations, and those parts are held together by foundational principles such as those governing the sources of international law and state responsibility for internationally wrongful acts.2

Notwithstanding its international legal system emphasis, international law teaching and scholarship frequently touches on national law, national courts and non-state actors. For example, it examines the status of international law in national courts and of non-state actors as both potential subjects of and contributors to the development of international law. 3 But it is less common for international law teaching and scholarship to treat national law, national courts or non-state actors as playing independently important roles in global affairs, apart from any connection they may have with international law.4

1 See, e.g., Mary Ellen O'Connell, Richard F. Scott, NaOmi RoHT-Arriaza \& DANiEl Bradlow, The INTERNATIONAL Legal SYSTEM: CASES AND MATERIALS (7th ed., Foundation Press, 2015); Dinah Shelton (ed.), COMMITMENT AND COMPLIANCE: THE ROLE OF NON-BINDING NORMS IN THE INTERNATIONAL LEGAL SYSTEM (Oxford University Press, 2003).

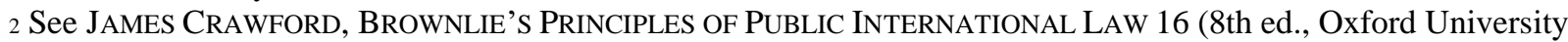
Press, 2012) ("International law has the characteristics of a system, not just a random collection of rules: the basic constructs of personality, sources (including treaties), interpretation, and responsibility, provide a framework within which rules may be generated, applied and, increasingly, adjudicated upon.").

3 See, e.g., ANDRÉ NOlLKAEMPER, NATIONAL COURTS AND THE InTERNATIONAL RUle OF LAW (Oxford University Press, 2011) (discussing national courts in the international legal system); Jean d'Aspremont (ed.), PARTICIPANTS IN THE INTERNATIONAL LEGAL System: MUlTiPLE PERSPECTIVES ON NON-STATE ACTORS IN INTERNATIONAL LAW (Routledge, 2011) (discussing non-state actors in the international legal system).

4 But see, e.g., Terence C. Halliday \& Gregory Shaffer, Transnational Legal Orders, in Terence C. Halliday \& Gregory Shaffer (eds.), TRANSNATIONAL LEGAL ORDERS (Cambridge University Press, 2015) (developing concept of transnational legal ordering); TONYA L. PUTNAM, COURTS WITHOUT BORDERS: LAW, POLITICS, AND U.S. EXTRATERRITORIALITY (Cambridge University Press, 2016); Christopher A. Whytock, Domestic Courts and Global Governance, 84 TULANE LAW REVIEW 67 (2009) (discussing not only relationship between national courts and international legal system, but also independent role of national courts in transnational dispute resolution and global governance). In addition, several casebooks take an approach that emphasizes not only international law and international courts, but also national law and national courts, as well as private norms and private forms of dispute resolution. See, e.g., Donald EARl Childress III, Michael D. RAMSEY \& Christopher A. Whytock, 
One of the enduring and important contributions of Philip Jessup's Transnational Law5 is its challenge to this concept of the international legal system. Jessup does not challenge the concept on the ground that international law is not a system, as others have. 6 Rather, he challenges it on what are essentially functionalist grounds. Rejecting the traditional doctrinal boundaries of the field of international law, his point of departure is a concern with "the problems of the world community" - not merely with "the relations of one nation (or state) to other nations (or states)" as the term "international" implies.7 He then asks: What are the rules that regulate these problems? The answer, he argues, is not only international law, but "all law which regulates actions or events that transcend national frontiers," including national law and private norms.8 Jessup called this law "transnational law."9

My argument in this chapter is that a further conceptual move would be helpful, from a concept of the "international legal system" to a concept of the "global legal system." Jessup's transnational law concept is a concept of law that reaches beyond international law. But we also need a concept of legal system that reaches beyond the international legal system - one that, unlike transnational law, encompasses not only the law that governs cross-border problems, but also courts and other national, international and private institutions that contribute to that same function.

The term "global legal system" is not new.10 But it is usually used without definition or with only abbreviated conceptual development. Moreover, scholars sometimes use the term

Transnational LaW \& Practice (Wolters Kluwer, 2015); Mathias W. Reimann, James C. HathaWAy ET Al., Transnational LAW: CASES AND MATERials (West, 2013); and DetleV F. VAGTS, William S. DodGE \& Harold Honguu KoH, Transnational Business Problems (4th ed., Foundation Press, 2008).

5 Philip C. Jessup, Transnational LAW (Yale University Press, 1956).

6 For an overview of the systemic view of international law and a discussion of critiques of that view, see Eyal Benvenisti, The Conception of International Law as a Legal System, 50 GERMAN YEARBOOK OF INTERNATIONAL LAW 393 (2008).

7 JESSUP, supra note 5, at 1.

8 JESSUP, supra note 5, at 2 .

9 See JESSUP, supra note 5, at 2 ('I shall use instead of 'international law,' the term 'transnational law' to include all law which regulates actions or events that transcend national frontiers.").

10 See, e.g., GiUliana ZicCARDi CAPAldo, The Pillars of Global LAW XVI (Routledge, 2008) (examining four pillars of the global legal system, including verticality and sharing of decisional processes, legality principles and common global values, integration of legal systems, and collective guarantees); Oren Perez, Purity Lost: The Paradoxical Face of the New Transnational Legal Body, 33 BROOKLYN JOURNAL OF INTERNATIONAL LAW 1, 3-4 (2007); Sabino Cassese, Global Standards for National Administrative Procedure, 68 LAW \& CONTEMPORARY Problems 109, 121 (2005); Eve Darian-Smith, Structural Inequalities in the Global Legal System, 34 LAW \& SOCIETY REVIEW 809 (2000); Mohamed S. Helal, Justifying War and the Limits of Humanitarianism, 37 FORDHAM InTERnATIONAl LaW Journal 551, 555 (2014); Sung-Soo Han, A Study on the Development of a Global Community from a Legal Perspective, 7 BRIGHAM Young UNIVERSITY INTERNATIONAL LAW \& MANAGEMENT REVIEW 71, 72 (2010); Andreas Fischer-Lescano \& Gunther Teubner, Regime-Collisions: The Vain Search for Legal Unity in the Fragmentation of Global Law, 25 MichigAN JOURNAL OF INTERNATIONAL LAW 999, 1007 (2004); Charles H. Koch, Jr., Envisioning a Global Legal Culture, 25 MiCHIGAN JOURNAL OF INTERNATIONAL LAW 1, 4 (2003); AnNe MARIE Slaughter, A New World Order (Princeton University Press, 2004); Chris Thornhill, The Global Legal System and the Procedural Construction of Constituent Power, 5 GLOBAL ConstiTUTIONALISM 405 (2016); Paul Schiff Berman, From Legal Pluralism to Global Legal Pluralism, in: Richard Nobles \& David Schiff (eds.), LAw, SOCIETY AND COMMUNiTy: SOCIO-LEGAL ESSAYS IN HONOUR OF ROGER COTTERRELL 255 (2014). 
"global law" in a way that includes courts and other institutions beyond legal rules.11 Indeed, the concept of a global legal system is implicit in Jessup's Transnational Law. It includes discussions of national courts and arbitration, and of conflict-of-laws rules, which, as I will suggest below, play a central role in what I am calling the global legal system. But these discussions fit uncomfortably within Jessup's concept of transnational law, which is defined in terms of rules. A clear concept of the global legal system can accommodate and make explicit these important implications of Jessup's work.

In this chapter, I outline my concept of the global legal system and attempt to lay out a coherent and parsimonious framework for understanding and analyzing it. To preview: The global legal system consists of institutions that provide legal solutions to transnational problems. These institutions are national, international, private, and sometimes hybrid. Among the types of solutions provided by the global legal system are three generic governance functions: prescription, adjudication and enforcement. Often more than one institution may provide solutions to a given transnational legal problem, creating a need for choice across three dimensions: national-national, national-international, and public-private. The global legal system uses three types of principles to guide these choices: principles of authority, principles of allocation, and principles of party autonomy. These are among the principles that hold the global legal system together, in spite of its high degree of decentralization.

\section{Transnational Problems: Function and Politics}

The global legal system is the system of laws, courts and other institutions that provide legal solutions to transnational problems. This is a functional understanding of the global legal system, and it follows Jessup's functional understanding of transnational law.12 His emphasis throughout is not on actions or events as such, but on problems and the law that can be used to solve them. As he puts it on the first page of Transnational Law, he is interested in "analyzing the problems of the world community and the law regulating them." 13 And each of the three main parts of the book is explicitly focused on problems for which he explores legal solutions: "The Universality of the Human Problems," "The Power to Deal with the Problems," and "The Choice of Law Governing the Problems."

So to understand what transnational law is - and what the global legal system does - we need to understand what transnational problems are. Jessup defined transnational problems very broadly. Transnational problems are problems that arise out of any "actions or events that transcend national frontiers." 14 They are the problems faced by the "world community," which "begin[s] with the individual and reach[es] on up to the so-called 'family of nations' or "society

11 One of the most comprehensive accounts of "global law" to date is GIULIANA ZICCARDI CAPALDO, THE PILLARS OF GLOBAL LAW (Routledge, 2008).

12 See JESSUP, supra note 5, at 71 (referring to "the function of transnational law"). See also Gralf-Peter Calliess, Transnational Law, in Helmut K. Anheier \& Mark Juergensmeyer (eds.), ENCYCLOPEDIA OF GLOBAL STUDIES (SAGE Publications, 2012) (“Generally speaking, Jessup's approach to transnational law can be categorized as a functional one.").

13 JESSUP, supra note 5, at 1.

14 JESSUP, supra note 5, at 2. 
of states." 15 "The problems in general," he explains, "arise from conflicts of interest or desire, real or imagined." 16

This definition of transnational problems reflects Jessup's claim that it is arbitrary to focus narrowly on international (that is, nation-to-nation) problems alone. Jessup was concerned with the problems faced by the "world community" more broadly. He argued that "the term 'international' is misleading, since it suggests that one is concerned only with the relations of one nation (or state) to other nations (or states)." 17 For Jessup, transnational problems can involve "individuals, corporations, states, organizations of states, or other groups."18 And he emphasized that the problems of interest to him are "after all merely human problems which might arise at any level of human society_individual, corporate, interregional, or international."19

Some have criticized Jessup's definition of transnational law as too broad to be useful because transnational problems are so pervasive that arguably every problem today is transnational.20 A global legal system paradigm inspired by Jessup's notion of transnational problems might be susceptible to the same criticism. But Jessup deliberately left his definition open, suggesting that it is best to "avoid further classification of transnational problems and further definitions of transnational law." 21 This open approach is sensible. Comparative legal scholars have criticized functionalism in comparative law for its tendency to assume that all societies face similar problems that define the function of law.22 It would also seem reasonable to resist too much generalizing about what those problems are in a functional approach to the global legal system. Moreover, human problems evolve over time. Cross-societal and inter-temporal variation in human problems makes it unwise, perhaps even impossible, to specify a priori what transnational problems are.

Perhaps most important is something that Jessup did not emphasize in Transnational Law: The definition of transnational problems can be highly political. Different individuals and groups can disagree about what constitutes a problem and how that problem should be defined. 23 Because legal solutions almost inevitably have distributional consequences or reflect different normative values, there is contestation over whether particular phenomena count as transnational problems. The production of legal solutions depends largely on how this contestation is

\footnotetext{
15 JESSUP, supra note 5, at 1.

16 JESSUP, supra note 5, at 11.

17 JESSUP, supra note 5, at 1.

18 JESSUP, supra note 5, at 3 .

19 JESSUP, supra note 5, at 15-16. It is interesting that Jessup's insistence on a non-state-centric view came more than a decade before a similar move in U.S. political science in the 1970s to include the study of "transnational relations" alongside international relations. See Joseph S. Nye, Jr. \& Robert O. Keohane, Transnational Relations and World Politics: An Introduction, 25 InTERnATIONAL ORGANIZATION 329 (1971).

20 See Christian Tietje \& Karsten Nowrot, Laying Conceptual Ghosts of the Past to Rest: The Rise of Philip C. Jessup's 'Transnational Law' in the Regulatory Governance of the International Economic System, in: Christian Tietje, Alan Brouder \& Karsten Nowrot (eds.), TrANSNATIONAL LAW REVISITED: ON THE OCCASION OF THE 50TH ANNIVERSARY OF ITS PUBLICATION 17, 30 (2006) (describing, but not endorsing, this critique) (available at http://www.wirtschaftsrecht.uni-halle.de/sites/default/files/altbestand/Heft50.pdf).

21 JESSUP, supra note 5, at 7.

22 See Christopher A. Whytock, Legal Origins, Functionalism, and the Future of Comparative Law, 2009 BRIGHAM Young UNIVERSITY LAW REVIEW 1879, 1886 (2009) (discussing these criticisms).

23 Id. at $1889-90$.
} 
resolved - and how it is resolved may be strongly influenced by the global distribution of power among states and between states and non-state actors.24

Therefore, to define the concept of the global legal system, I suggest a broad, functionalist concept of transnational problems similar to Jessup's: Transnational problems are problems that concern more than one state or persons of different nationalities. Defined this way, transnational problems include not only international problems, but also problems relevant to non-state actors. It must be a realistic functionalist concept that avoids excessive generalization and recognizes the politics of transnational problems.

\section{LEGal Solutions AND GENERIC GovernanCE FunCTIONS}

If the first step toward defining the concept of a global legal system is to define transnational problems, the next step is to understand the nature of legal solutions to those problems. Jessup suggests that as human problems change and grow, there is growing demand for legal solutions to those problems: "As man has developed his needs and his facilities for meeting his needs, the rules become more numerous and more complicated." 25 Transnational law is the field of law that provides those solutions. Thus, as Jessup puts it, transnational law "suppl[ies] a...storehouse of rules on which to draw" to solve transnational problems.26

Like problem-definition, it is important not to pretend that the definition of solutions is apolitical. Which solutions are proposed and adopted will often be politically contested and influenced by power. It also is important not to pretend that legal solutions are necessarily effective in the sense that they actually solve the transnational problems to which they are addressed. The effect of a legal solution is an empirical question that poses difficult challenges of causal inference - and whether a particular effect makes a solution a "success" is likely to be as politically contested as the definition of the transnational problem and the selection of a solution in the first place.27 What might be a success to one group could be viewed by another group as a failure or as making a problem worse. Even more fundamentally, law alone cannot of course solve all (or even most) transnational problems. Therefore, it is best not to think of legal solutions as necessarily effective, but rather to think of them as potential solutions to be assessed based on evidence.

Jessup made no effort to catalog transnational problems in detail, and he made no effort to list the solutions offered by transnational law, either. Yet it is helpful to think about solutions to transnational problems at a very general level, with a focus on a trio of generic governance functions: prescription (the making of rules), adjudication (the authoritative resolution of disputes), and enforcement (namely, the enforcement of rules and the outcomes of adjudication).28 These generic functions may help address many different transnational problems,

24 This contestation may occur national and transnationally. See generally Halliday \& Shaffer, supra note 4.

25 JESSUP, supra note 5, at 8 .

26 JESSUP, supra note 5, at 15 .

27 See generally Christopher A. Whytock, Legal Origins, Functionalism, and the Future of Comparative Law, 2009 BRIGHAM YOUNG UNIVERSITY LAW REVIEW 1879 (2009).

28 See Anne Mette KJAer, Governance (Polity Press, 2004) (defining governance as "governance is "the setting of rules, the application of rules, and the enforcement of rules"). These functions roughly correspond to the three types of authority addressed by the customary international law of jurisdiction. See SEAN D. MURPHY, PRINCIPLES 
ranging from transnational crime to cross-border environmental harm, and from human rights abuses to international child custody disputes. They are not the only functions, but they are a good point of departure for thinking about the functions of the global legal system. 29

\section{SuPPliers OF Legal Solutions: The InSTITUTIONS OF THE GLOBAL LEGAL SySTEM}

The next step in honing the concept of a global legal system is to ask: Who supplies legal solutions? Jessup emphasized that the suppliers of transnational law include not only states, but also international organizations and private actors. He includes in his concept of transnational law rules made by "ecclesiastical authorities," corporations, "secret societies," towns, cities, states, and international organizations. 30

Likewise, the suppliers of legal solutions in the global legal system include not only states, but also other institutions. These institutions can be differentiated functionally (Table 1) and organizationally (Table 2). Functionally, there are institutions that correspond to each of the generic functions of the global legal system: institutions that prescribe rules (e.g. legislatures and sometimes courts), institutions that adjudicate (e.g. courts and private dispute resolution bodies, such as arbitral tribunals), and institutions that enforce (e.g. groups of nations or private groups taking law into their own hands).

\begin{tabular}{|c|}
\hline Table 1 \\
Institutions of the Global Legal System Differentiated by Generic Governance Function \\
\hline Prescription \\
Adjudication \\
Enforcement \\
Hybrid \\
\hline
\end{tabular}

Organizationally, the institutions of the global legal system include national institutions (e.g. national legislatures and national courts), international institutions (e.g. the United Nations), and private institutions (e.g. private rule-making bodies and private dispute resolution bodies,

OF INTERNATIONAL LAW (2nd. ed., West, 2012), 313-344 (discussing jurisdiction to prescribe, jurisdiction to adjudicate, and jurisdiction to enforce).

29 See, e.g., LUNG-CHU CHEN, AN INTRODUCTION TO CONTEMPORARY INTERNATIONAL LAW: A POLICY-ORIENTED PERSPECTIVE (Oxford University Press, 2015) (identifying seven functions of the international legal system: the intelligence (information) function, the promoting function, the prescribing (lawmaking) function, the invoking function, the applying function, the terminating function, and the appraising function).

30 JESSUP, supra note 5, at 8-9. In this way, Jessup's concept of transnational law can be considered a precursor to the concept of global legal pluralism. See generally Ralf Michaels, Global Legal Pluralism, 5 ANNUAL REVIEW OF LAW \& SOCIAL SCIENCE 1-35 (2009); Paul Schiff Berman, Global Legal Pluralism, 80 SOUTHERn CALifornia LAW REVIEW 1155 (2007). 
such as arbitral institutions). Often, institutions are hybrid, with a combination of prescriptive, adjudicative and enforcement functions, or a combination of national, international and private elements.

There are also subsystems of the global legal system. Subsystems vary by participants and the types of problems they address. National legal systems are subsystems in which participation is limited to a given state. International legal subsystems often have a limited number of participating states, with those limits often defined regionally (e.g. the African Court on Human and Peoples' Rights), and many are focused on particular types of problems (e.g. the World Trade Organization and the International Criminal Court).

\begin{tabular}{|c|}
\hline Table 2 \\
Institutions of the Global Legal System Differentiated by Organizational Level \\
National \\
International \\
Private \\
Hybrid \\
\hline
\end{tabular}

The global legal system is highly decentralized - so decentralized that some might hesitate to call it a "system" at all.31 Needless to say, there is no global court or global legislature. However, centralization is not necessary for a system to exist.32 Rather, centralization is a variable, such that a system can be more or less centralized (or more or less fragmented). In any event, some subsystems of the global legal system are quite centralized (e.g. most national legal systems and, one might add, the European Union). Most fundamentally, there are legal rules that are part of the global legal system that contribute to the coordination of its different parts, including national (and, increasingly, international) conflict-of-laws rules; public international law's principles of jurisdiction to prescribe, adjudicate and enforce; the national and international law of arbitration; and the host of principles that govern the relationships between

31 The status of international law as a system has been widely discussed, along with the implications of fragmentation for that status. See, e.g., JAN KlabBERS, AnNE PETERS \& GEIR Ulfstein, THE

CONSTITUTIONALIZATION OF INTERNATIONAL LAW (Oxford University Press, 2009); International Law Commission, Fragmentation of International Law: Difficulties Arising from the Diversification and Expansion of International Law, UC Doc. A/CN.4/L.682/Corr.1 (Aug. 11, 2006) (finalized by Martti Koskenniemi).

32 Cf. Giuliana Ziccardi Capaldo, Managing Complexity within the Unit of the Circular Web of the Global Law System: Representing a "Communal Spider Web," 1 GLOBAL COMMUNITY YEARBOOK OF INTERNATIONAL LAW \& JURISPRUDENCE xxi (2011) (affirming that "[t]he global law system is highly fragmented" but nevertheless treating it as a system). 
different rules of international law (such as the maxims of lex specialis derogat legi generali and lex posterior derogat legi priori and the concept of jus cogens norms).33

\section{Legal Rules: Beyond Traditional Doctrinal Distinctions}

One type of legal solution provided by the institutions of the global legal system is the production of legal rules - that is, prescription, which is one of the generic functions of the global legal system. Nations create national law. Acting together, nations create international law, including customary international law and treaty law. And private actors also create rules. All three types of rules are part of transnational law, according to Jessup.

This conception of transnational law was - and to a significant degree still is - innovative in several ways.34 First, it challenges the distinction between national law and international law. As Jessup argued, "the line between the international and the national should be questioned as a basis for legal classification...." 35 The distinction may in many situations be doctrinally relevant, but from Jessup's functional perspective, the essential commonality is that both national law and international law can provide potential solutions to transnational problems. Second, Jessup challenged the distinction between public international law and private international law. According to Jessup, "[b] oth public and private international law are included" in the concept of transnational law.36 Third, Jessup didn't hesitate to include private rules in his definition of transnational law.37

It is not obvious whether to include concepts like "soft law" and "non-state law" in the concept of a global legal system. On the one hand, there are good reasons to reserve the term "law" for rules that are produced by a recognized lawmaking process - such as those defined in a national constitution or international law's doctrine of sources - and intended to be legally binding in the sense that a court would consider them to be binding rules of decision in adjudication. Legal scholars and social scientists have long sought to understand what is distinctive about law. Normatively, is there a difference between legal obligations and other types of obligations? Behaviorally, do legal rules affect behavior in ways that are systematically different from other types of rules? And how do legal rules affect, and how are they affected by, non-legal rules? 38 But if one conflates legal and non-legal rules into a single concept of law, this type of analysis is not possible.

${ }_{33}$ Cf. International Law Commission, supra note 31, at 7 (noting that notwithstanding fragmentation, international law is a system due largely to these and other principles of international law).

34 For an overview of the concept, its evolution, and its adoption by different theoretical schools of international law, see Harold HongJu KoH, Transnational Litigation In United STATES CourTs ch. 1 (Thomson

Reuters/Foundation Press, 2008).

35 JESSUP, supra note 5, at 70.

36 JESSUP, supra note 5, at 2.

37 He downplayed this move, saying that "[n]owadays it is neither novel nor heretical to call all of these rules "law.", JESSUP, supra note 5, at 9. But actually, this may have been one of the more novel aspects of Jessup's concept at the time.

38 See Martha Finnemore, Are Legal Norms Distinctive?, 32 NEW YORK UNIVERSITY JOURNAL OF INTERNATIONAL LAW AND POLITICS 699, 701 (2000) (arguing that one of the most important questions for political scientists and policy makers is whether "legal norms, as a type, operate differently from any other kinds of norms in world politics"). 
On the other hand, so-called "soft law" and non-state law play a crucial role in solving transnational problems, as Jessup emphasized. 39 They are also so closely linked to legally binding rules as to make it difficult to consider the role of one without the other.40 For example, non-legally binding and private rules may influence the development of law, and private rules that take the form of, or are incorporated into, contracts may be legally enforceable as a matter of contract law. And from Jessup's functional perspective, the differences between legally binding rules, non-legally binding rules and private rules are not as fundamental as what they all have in common: They are all potential solutions to transnational problems. I therefore include nonlegally binding rules and private rules as among the rules of the global legal system; but in an effort to avoid the analytical problems posed by conflating them with law, I do not use the terms "soft law" or "non-state law" to describe them.

\section{Dimensions of CHOICE}

An important implication of a global legal system concept based on Jessup's functionalist concept of transnational law is that a wide variety of legal solutions may be available for a given transnational problem. As Jessup explains:

There are rules, or there is law, bearing upon [transnational problems]. There may be a number of applicable legal rules and they may conflict with each other. When this is the case, still other rules may determine which law prevails. In certain types of situations we may say this is a question of "choice of law" which is to be determined by the rules of "Conflict of Laws" or "Private International Law." The choice usually referred to here is between rules of different national laws; and the choice, we assume, is to be made by a national court. In other types of situations the choice may be between a rule of national law and a rule of "Public International Law," and the choice may be made by a national tribunal or by some nonjudicial decision maker.41

In other words, since nations, international institutions, and private actors can all provide legal solutions to transnational problems, there are multiple dimensions to choosing a legal solution (see Figure 1). First, will a national or international solution be used? Second, will a national or private solution be used? Third, will an international or private solution be used? 42 And beyond these three basic dimensions, there are others: between multiple national solutions, international solutions, or private solutions, which will be used?

39 See, e.g., Dinah Shelton, Commitment and Complance: The Role of Non-Binding Norms in the INTERNATIONAL LEGAL SYSTEM (Oxford University Press, 2003) (on non-binding rules) and TIM BÜTHE \& WALTER Mattli, The New Global Rulers: The Privatization OF Regulation In the World ECONOMY (Princeton University Press, 2011) (on private forms of governance).

40 See Christopher A. Whytock, Private-Public Interaction in Global Governance: The Case of Transnational Commercial Arbitration, 12:3 BUSINESS \& POLITICS (2010).

${ }_{41}$ JESSUP, supra note 5, at 4-5.

42 See Whytock, Domestic Courts and Global Governance, supra note 4. 


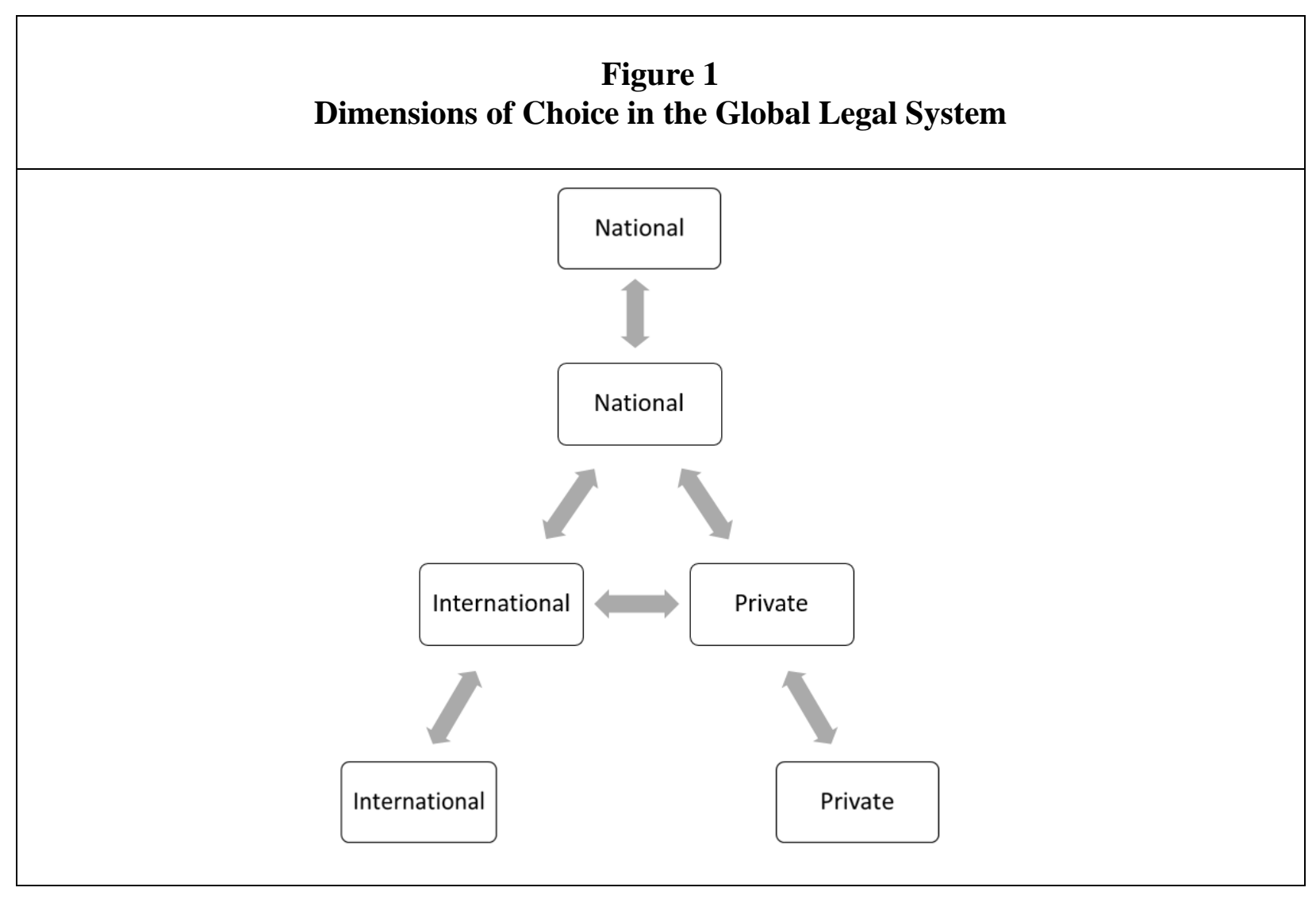

These dimensions intersect with the three generic functions of prescription, adjudication and enforcement (Table 3).43 Which rules should be applied? Which court or other body should adjudicate? Who should enforce? And for each of these generic governance functions, the questions are: Which nation? National or international? Private or public? To understand the global legal system, it is essential to understand these dimensions of choice.

43 See Whytock, Domestic Courts and Global Governance, supra note 4. As noted above, there are of course other functions of the global legal system. For example, both the Human Rights Council's universal periodic review process (at the international level) and nongovernmental human rights organizations (at the private level) perform what Chen calls an "intelligence" function, a function that does not fit neatly into the category of prescription, adjudication, or enforcement. $C f$. CHEN, supra note 29 (listing the UN Human Rights Council's reporting system as an example of the "intelligence" function.). 


\begin{tabular}{|c|c|c|c|c|}
\hline \multicolumn{5}{|c|}{$\begin{array}{c}\text { Table } 3 \\
\text { Institutions of the Global Legal System: Functions and Organization (with Examples) }\end{array}$} \\
\hline & & & $\begin{array}{l}\text { Organizational } \\
\text { Level }\end{array}$ & \\
\hline & & National & International & Private \\
\hline & Prescription & national legislatures & $\begin{array}{l}\text { treaty-making, } \\
\text { regulations of } \\
\text { regional (e.g. EU) or } \\
\text { specialized (e.g. } \\
\text { ILO) organizations } \\
\end{array}$ & $\begin{array}{l}\text { private rulemaking } \\
\text { bodies (e.g. ISO) }\end{array}$ \\
\hline \multirow[t]{2}{*}{$\begin{array}{l}\text { Governance } \\
\text { Function }\end{array}$} & Adjudication & national courts & $\begin{array}{l}\text { international courts } \\
\quad(\text { e.g. ICJ) }\end{array}$ & $\begin{array}{l}\text { transnational } \\
\text { arbitral institutions } \\
\quad(\text { e.g. ICC) }\end{array}$ \\
\hline & Enforcement & $\begin{array}{c}\text { police, national } \\
\text { executive agencies }\end{array}$ & $\begin{array}{l}\text { UN Security } \\
\text { Council, economic } \\
\text { sanctions }\end{array}$ & $\begin{array}{l}\text { reputational } \\
\text { monitoring and } \\
\text { reciprocity }\end{array}$ \\
\hline
\end{tabular}

\section{Methods OF CHOICE}

But how are these choices made? Whether through national law, public international law or private international law, argued Jessup, one "function of transnational law [is] to reshuffle the cases and to deal out jurisdiction in the manner most conducive to the needs and convenience of all members of the international community." 44 The global legal system uses three basic methods to guide choices across these dimensions: authority, allocation, and party autonomy. First, a choice may be included or excluded from consideration based on whether the supplier has the authority to apply a particular solution. This method is most familiar in public international law, a branch of which provides principles limiting the jurisdiction of states to prescribe, adjudicate and enforce. A given nation either has or lacks authority to prescribe, adjudicate or enforce.

Second, a choice may be made based on rules of allocation. The question is not whether a given supplier has authority, but rather which solution among several will be applied to a transnational problem. Ordinarily, this method assumes - implicitly or explicitly - that the suppliers of the solutions under consideration have the requisite authority, and in that way authority and allocation are related.45 Perhaps the most familiar example of allocation as a

44 JESSUP, supra note 5, at 71.

45 See Christopher A. Whytock, Toward a New Dialogue Between Conflict of Laws and International Law, 110 AMERICAN JOURNAL OF INTERNATIONAL LAW UNBOUND 150 (2016). 
method of choice is the choice-of-law branch of conflict of laws (or "private international law"), which attempts to guide judges and lawyers in figuring out which state's law to apply.46

Third, a choice may be made not based on rules of authority or allocation, but instead based on party autonomy.47 The most common examples are choice-of-law clauses in contracts, whereby parties choose a particular nation's law (or even rules other than national law, such as the UNIDROIT Principles of International Commercial Contracts), or dispute resolution clauses, whereby parties choose a particular nation's courts or a private dispute resolution method such as arbitration. There can also be some degree of party autonomy regarding enforcement, such as through private escrow arrangements.

\begin{tabular}{|c|l|}
\hline \multicolumn{2}{|c|}{$\begin{array}{c}\text { Table } 4 \\
\text { Methods of Choice in the Global Legal System (with Examples) }\end{array}$} \\
\hline Method & Examples \\
\hline Authority & $\begin{array}{c}\text { Customary International Law Principles of } \\
\text { Jurisdiction to Prescribe, Adjudicate and } \\
\text { Enforce }\end{array}$ \\
\hline Allocation & $\begin{array}{c}\text { Choice-of-Law Branch of Conflict of Laws } \\
\text { (Private International Law) }\end{array}$ \\
\hline Party Autonomy & \begin{tabular}{c} 
Choice-of-Law and Forum Selection Clauses \\
\hline
\end{tabular} \\
\hline
\end{tabular}

The branch of law that most explicitly deals with choice - conflict of laws - deals primarily with the international dimension (and, to a lesser extent, with the private-public dimension).48 For example, choice of law deals with which nation's law to apply, not whether to apply national law or international law. But each nation has domestic rules that help determine when one of its courts will apply international law rather than national law, which is an example of the national-international dimension; and most nations have rules that help determine when

46 See Alex Mills, The Confluence of Public and Private International Law: Justice, Pluralism And SUBSIDIARITY IN THE INTERNATIONAL CONSTITUTIONAL ORDERING OF PRIVATE LAW (Cambridge University Press , 2009) and Whytock, Domestic Courts and Global Governance, supra note 4 (discussing allocation of governance authority by conflict of laws).

${ }_{47}$ See AleX Mills, Party Autonomy in Private InTernational Law (Cambridge University Press, 2018). Of course, rules governing party autonomy also can be understood as involving allocation — namely, allocation between state and private authority.

${ }_{48}$ Conflict of laws can also deal with choice among the governmental subunits of federal systems (e.g. among U.S. states in the U.S. federal system). 
one of its courts will enforce a choice-of-law or forum selection clause, which is an example of the private-public dimension.

These methods of choice are important in legal practice, yet they are contested and vary significantly across legal systems. The future development of the global legal system will thus depend largely on the further development of rules of authority, allocation, and party autonomy. But the choices themselves are not merely legal, but also political: They distribute governance power among states, between national and international institutions, and between private and public actors. For this reason, these choices - like the definition of problems and the evaluation of solutions - inevitably have a political aspect.

\section{FROM INTERNATIONAL LAW AND INTERNATIONAL RELATIONS TO LAW AND WORLd POLITICS}

The global legal system concept can benefit teaching, legal practice, and scholarship by providing a coherent way of thinking about the multiple transnational problem-solving functions of a legal system (including prescription, adjudication and enforcement) and the multiple levels at which those functions are performed (including national, international and private). For teaching, the global legal system concept can help train students to identify legal solutions without limiting themselves to national (or international) law. For lawyers, it can offer a coherent way to make sense of the complex legal environment in which they try to help clients solve their transnational problems.

For scholars, it puts in focus a wide range of questions about coordination among the different institutions of the global legal system, and about the appropriate roles of authority, allocation and party autonomy in the choice of legal solutions to transnational problems. And it helps to highlight weaknesses - such as the relative underdevelopment of principles for allocating between national and international solutions, among different international solutions, and between national and private solutions. The global legal system concept also brings into focus questions about contestation over the definition of transnational problems, the design of legal solutions, the measurement of outcomes, the assessment of solutions, and the legal and political determinants of decisions regarding the allocation and exercise of national, international and private authority to govern transnational problems.

More broadly, the global legal system concept implies a move away from the current international law and international relations (IL/IR) paradigm in interdisciplinary international law scholarship. 49 As its label suggests, IL/IR research tends to be state-centric and focuses primarily on international law and international courts. It therefore tends to neglect the two other principal dimensions of the global legal system - the national and the private.

But interdisciplinary scholarship is increasingly taking what I call a "law and world politics" (L/WP) approach.50 Moving beyond the somewhat narrow focus on international law

49 See Jeffrey L. Dunoff \& Mark A. Pollack (eds.), InTERDisciPlinARY PERSPECTIVES ON INTERNATIONAL LAW AND International Relations: THE StATE of THE ART (Cambridge University Press, 2012).

50 See Christopher A. Whytock, From International Law and International Relations to Law and World Politics, in: William R. Thompson (ed.), OXFORD RESEARCH ENCYClOPEDIA OF POLITICS (Oxford University Press, 2018). 
and international courts indicated by the "IL" in IL/IR scholarship, L/WP scholars are bringing national law and national courts into the analysis, shedding light not only on how they support (and sometimes undermine) international law and international courts, but also on their direct role in core areas of international relations, such as international conflict and foreign policy. Moving beyond the state-centric tendencies reflected by the "IR" in IL/IR scholarship, scholars are bringing research on law up to speed with the broader world politics trend in political science by studying aspects of law-including extraterritoriality, conflict of laws, private international law, and the law of transnational commercial arbitration - that govern the transnational activity of private actors and that support (and sometimes undermine) private governance. And moving beyond the domestic-international divide, political scientists are increasingly rejecting the traditional distinction between "hierarchical" domestic law and "anarchical" international law, and beginning to take advantage of theoretical convergence across the domestic, comparative and international politics subfields to develop a better general understanding of law and politics that does not rely on the traditional hierarchy/anarchy distinction.51

This L/WP trend in interdisciplinary scholarship is consistent with (and might even seem necessary) from the perspective of Jessup's functionalist concept of transnational law. It promises to provide a richer understanding of the global legal system than a largely state-centric approach that revolves primarily around international law and international courts.

51 See Christopher A. Whytock, Thinking Beyond the Domestic-International Divide: Toward a Unified Concept of Public Law, 36 GeOrgetown Journal OF InTERnATIONAL LAW 155 (2004) and Wayne Sandholtz \& Christopher A. Whytock, The Politics of International Law, in Wayne Sandholtz \& Christopher A Whytock (eds.), RESEARCH HANDBOOK ON THE POLITICS OF InTERnATIONAL LAW 1, 14-17 (Edward Elgar Publishing, 2017). See also Daryl J. Levinson \& Jack L. Goldsmith, Law for States: International Law, Constitutional Law, Public Law. 122 HARVARD LAW REVIEW 1791-1868 (2009); Shalev Roisman, Constraining States: Constitutional Lessons for International Courts, 55:3 Virginia Journal of InTERnATIONAL LAW 729-782 (2015); and Jeffrey K. Staton \& Will H. Moore, Judicial Power in Domestic and International Politics, 65 InTERNATIONAL ORGANIZATION 553-587 (2011). 